\title{
Factors of Distributed Photovoltaic Power Generation
}

\author{
Chunyan Ma \\ College of Electrical and Information Engineering, \\ University of Hubei Automotive Technology Shiyan \\ 442002; \\ College of Information Science and Engineering, \\ University of Wuhan Science and Technology Wuhan, \\ China,430081 \\ E-mail:mcyjsy@126.com
}

\author{
Shiying Jiang \\ College of Economy and Management, University Hubei \\ of Automotive Technology Shiyan 442002 \\ Ying Gong \\ Supply Power of Foshan, foshan, China, 528000 \\ E-mail:gongying@126.com
}

\begin{abstract}
Distributed photovoltaic power generation system can better alleviate the problems of energy shortage and environmental pollution. To save the photovoltaic industry, the state introduced continuous policiesy since 2012, strongly supported the development of distributed photovoltaic power generation industry. This paper analyzes China's photovoltaic power generation business model, and further analyzes factors that influence generation electricity.
\end{abstract}

Keywords-distributed photovoltaic power; key factors; operation mode

\section{INTRODUCTION}

Distributed photovoltaic power generation system is the distributed generation system that use photovoltaic modules to convert solar energy, small installed capacity and power generation capacity net in the nearest network with the characteristics of local conditions and clean and efficient and it can better alleviate the problems of energy shortage and environmental pollution. Currently, more than 60 countries around the world use a variety of policy tools to encourage the development of distributed Distributed Photovoltaic power industry.

The conflict of China's PV industry overcapacity has long history, 90 percent of PV modules need to be exported, and the risk of the photovoltaic industry is heavily dependent on foreign markets, exposed to exhaustive when the European and American "double reverse". To save the photovoltaic industry, the state introduced continuous policiesy since 2012, strongly supported the development of distributed photovoltaic power generation industry, and proposed that distributed PV will reach 10 million kilowatts in 2015, distributed photovoltaic power generation industry has broad prospects for development.

At present, the relevant research around the photovoltaic power generation is concentrated in which PV electricity price regulation policy research, pricing strategy of feed-in tariff, the PV of government subsidies research and distributed photovoltaic power generation forecasting. This paper analyzes China's photovoltaic power generation business model, and further analyzes factors that influence generation electricity.

\section{Operation Mode Of Distributed Photovoltaic POWER GENERATION SYSTEM IN CHINA}

At present, China's photovoltaic power generation project investment diversification, investment-driven power is complex, and the operating mode has not been fully straightened out. However, we can summary three kinds, namely unified purchase and marketing business model, contract energy management mode and user self-occupied mode. In addition, there are more than several models of hybrid model.

\section{A. Self-Occupied Mode}

This mode is that the users themselves construct the photovoltaic power plants, the priority electricity for their own use, the excess electricity access, and the lack of electricity is provided from the power grid. Distributed power and users are located in the same place, and are in the same corporate. In this mode, the user own priority electricity for their own use, excess electricity are sold to the grid in accordance with local coal desulfurization unit benchmark price businesses, while at full power to get government subsidies; The grid enterprises charged to the net electricity tariff at sales catalog price.

Currently, these projects by the users themselves are recovered the investment cost mainly by government subsidies and saving electricity fees. Part of the photovoltaic project investment employers are users who have the will to save and also have the ability to pay higher; Part is the remote areas user, part is hospitals with more high reliability requirements, and there is a considerable part of industrial and commercial users with large installed capacity.

\section{B. Purchasement Mode}

This mode is the third party investors is responsible for PV Investment, construction, operation and maintenance, and enjoy the rights to operate a photovoltaic power generation, all the electricity fed into the public grid, and power companies is responsible for the full acquisition of the photovoltaic power generation. In this mode, as a power source, the photovoltaic generation power basically through 110 (66), $35 \mathrm{kV}$ substation, medium or low voltage parent 
cable net in, then supply the end users. So users and photovoltaic power typically locate in different places.

Power investors will receive government subsidies construction or price subsidies: 1) In the way of construction subsidies, power suppliers at coal desulfurization unit benchmark price sold electricity to the grid business; 2) In the way of price subsidies, generation companies sold electricity to power companies at the Internet benchmark price, without taking access net fee and standby fee. This is a commonly used domestic carrier mode, especially those large wind farms and solar power plants are made to power directly to the Internet.

\section{Contract Energy Management Model}

It is that the third party investors invest in building photovoltaic power, generating capacity meet users in the same location of the photovoltaic power in priority, the extra power access the Internet, the shortage electric power by electricity companies to users at local net sales price. In this mode, the PV inverter is directly to the user after the low-voltage grid, and the investors get government subsidies at full power. The PV excess energy in accordance with the benchmark price of domestic coal desulfurization unit purchased by power companies, power supply business charge the net amount of electricity to the user in accordance with local sales catalog price.

This model truly PV-place consumptive, more electricity will be sold, shortage mainly be supplied by city electricity. In this mode, PV project investment motivation is more complex, there are both spontaneous self with oriented projects, and fewer personal use mainly supplied to others, as well as supplying all items used by others.

\section{Mixed Mode}

It is basically a combination of any two kinds or three kinds of modes in above three modes. The large-scale PV demonstration projects invested and constructed by companies generally use mixed mode. For example, EcoCity Investment Company since construction and power for their own distributed photovoltaic power generation facilities, according to "self operations from the bottom with a "model; construction sites and in other units for single bit distributed PV power facilities, according to the contract energy management mode; the use of public space construction of photovoltaic facilities, using purchase and unified sales mode. Thus, while the entire demonstration project use a mixed mode, it is still a single operating mode for single project.

\section{Factors Of Photovoltaic POWER}

Many short-term factors influence power generation prediction, such as various types conversion efficiency meteorological factors, location photovoltaic power plants, photovoltaic array rate, installation angle, time and season.

\section{A. The Angle of Incidence of Light on the Different Types of Cell Conversion Efficiency}

The angle of incidence of light include azimuth and inclination angle of incidence of light. Refering to the text, comparison test of all kinds of practical conversion efficiency of the battery under the plurality of illumination angle, the conclusion is: the affect of inclination on the crystalline and amorphous silicon cells cell conversion efficiency has the same trend, but the conversion efficiency is affected by changes in the magnitude of inclination crystalline silicon cells is weaker than amorphous silicon cells.

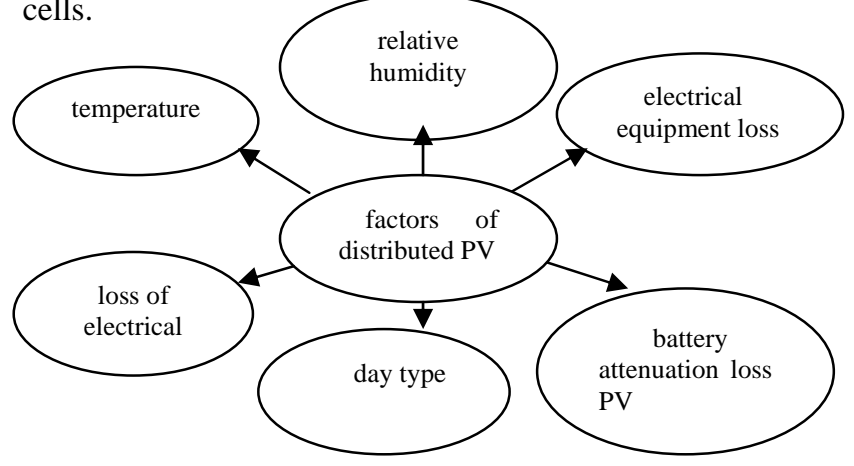

Figure 1. Factors of distributed PV

\section{B. Temperature}

It is indirect factor on straight photovoltaic panels photovoltaic panels power generation, and the ambient temperature indirectly affect power generation by influencing the temperature of the battery plate, such losses affect power generation is about $4.5 \%$. Solar array member of the rated power is measured under standard test conditions, when it in transport row, the battery temperature is higher than $25^{\circ} \mathrm{C}$, the output power will be reduced. Because the photoelectric conversion efficiency of the battery pack drop down with increasing temperature. The solar cell temperature increases $1{ }^{\circ} \mathrm{C}$, power is reduced by $0.35 \%$.If the ambient temperature is used directly as the working temperature of PV member, it will reduce the prediction accuracy of the prediction model. Therefore, it is necessary to distinguish between ambient temperature and real Interdepartmental working temperature of component models in forecasting model.

\section{Loss of Electrical Equipment}

The loss of electrical equipment includes an inverter losses, transformer losses, DC AC cable loss, the impact of electricity are about $3 \%, 2.5 \%$ and $2 \%$.The component connection loss affect power generation is about $2 \%$.Between the battery pack and to Junction box using a wire connection, connection is fine, and many connection point, wire resistive losses and poor contact connection point will cause losses.

\section{Day Type}

It directly affect the day of radiation intensity, temperature changes range and variation, which generally defines a day of electricity and variation. Under the same day, although power volume is slightly different, but the variation is same thereof. The photovoltaic power generation and variation vary greatly in different day types. 
In order to improve the pre-measurement accuracy, it should be point historical data into sunny, cloudy, and rain (snow) days based on the characteristics of day type.

\section{E. Relative Humidity on Generating Capacity}

Under the same day type, when ambient temperature and the temperature of photovoltaic panels is similar, the different relative humidity has also big impact on the photovoltaic power generation system. In cloudy weather, the electricity of relative low humidity of the day was significantly higher than the relative humidity higher day. The humidity reflects a more fine cause division for a same day type.

\section{F. Battery Attenuation Loss}

The impact of such loss on generating capacity is about $1 \%$ per year. The aging decay of polysilicon PV modules, mainly due to the battery's slow decline save and performance degradations and caused by packaging materials. The assembly material degradation is mainly due to ultraviolet radiation. That solar panels do not match loss such losses affect power generation about 1.3\%. Gridconnected PV power plant the cell matrix the battery module strings, in parallel, the ideal state is the operating current series with substantially the same, then the module string substantially the same operating voltage in parallel. But it is difficult to do in the actual security when loading, and for each component, its optimum operating voltage and current necessarily identical, resulting in total power of the entire phalanx is smaller than the sum of the individual components of power.

\section{CONCLUSION}

With the development of a lot of good policy about new energy industry, and new energy and network access technical condition matures, domestic large and mediumsized photovoltaic power plants centralized and distributed power stations networks in succession. PV industry technological advances have brought the cost of photovoltaic power plant construction declining.

The PV market is still a policy market, Changes of incentive policies has huge impact on the PV market and business. PV future business model depends on games between government, power companies and independent investors. To improve the photovoltaic power generation, we need to analyze a number of factors, and pay attention to key controling factors.

\section{ACKNOWLEDGMENT}

This paper received vigorous support of hubei province science and technology plan items (item number: (B2015122).We show deep gratitude to them.

\section{REFERENCES}

[1] Zhu Qunzhi, Si Leilei, Jiang Tingyan. Economical and environmental analysis of building photovoltaic systems with different installation styles[J]. Acta Energiae Solaris Sinica, 2012(1): 24-29(in Chinese).

[2] Caputo D, Grimaccia F, Mussetta M. Photovoltaicplants predictive model by means of ANN trained by a hybrid evolutionary
algorithm[C]//International Joint Conference on Neural Networks. Barcelona, Spain: 2010.

[3] Lü Zhong, Lan Feifei, Qu Juan. Photovoltaic generation experiment in solar power demonstration base and its benefit analysis meteorological[J] .Hydrological and Marine Instruments, 2011(4): 106-108(in Chinese).

[4] Li Guangming, Liao Hua, LiJingtian. Discussion on the method of grid-connected PV power system generation forecasting) [J].Journal of Yunnan Normal University: Natural Science Edition), 2011, 31(2):33-38, 64.

[5] Chakraborty S, Weiss M D, Simoes M G. Distributed intelligent energy management system for a single-phase highfrequency AC microgrid [J]. IEEE Trans on Industrial Electronics, 2007, 54(1): 97109.

[6] Langni O, Diekmann J, Lehr U. Advanced mechanisms for the promotion of renewable energy-Models for the future evolution of the German Renewable Energy Act[J]. Energy Policy, 2009, 37(4): 1289-1297.

[7] Campoccia A, Dusonchet L, Telaretti E, et al. An analysis of feed-in tariffs for solar PV in six representative countries of the European Union[J]. Solar Energy, 2014, 107: 530-542.

[8] Grösche P, Schröder C. On the redistributive effects of Germany's feed-in tariff[J]. Empirical Economics, 2014, 46(4): 1339-1383.

[9] Yang, P., Tang, G., \& Nehorai, A. (2013). A game-theoretic approach for optimal time-of-use electricity pricing. Power Systems, IEEE Transactions on, 28(2), 884-892.

[10] Chen, M. J., Hsu, Y. F., \& Wu, Y. C. (2014). Modified penalty function method for optimal social welfare of electric power supply chain with transmission constraints. International Journal of Electrical Power \& Energy Systems, 57, 90-96.

[11] SU Jian, ZHOU Limei, LI Rui.Cost-benefit Analysis of Distributed Grid-connected Photovoltaic Power Generation[J]. Proceedings of the CSEE, 2013, 33(34): 50-57.

[12] FAN Bin, YAO Yu, CHU Yan.International Policyof Distributed Photovoltaic Feed-in Tariffand Enlightenment to China[J].East China electric power, 2014,42(10):2197-2200.

[13] WANG Haiying, BAI Xiaomin, MA Gang, Reliability Assessment of Grid-Integrated Solar Photovoltaic System[J].Power System Technology, 2012, 36(10), 1-5.

[14] Shen zhong. influence analysis of solar photovoltaic power plant design factors[J]. Heilongjiang Science, 2013, 10: 74.

[15] Yang Jingtao, Jia Hui Jie Lv Guodong. factor analysis of the gridconnected photovoltaic power plant generating capacity[J]. Solar, 2013, 17: 40-45.

[16] Zhang Xueli, Liuqi Hui, Ma Huimeng, Li Bei. factor analysis of PV plant output power[J].Grid and clean energy, 2012, 28 (5): 75-81.

[17] Liu peiliang. factor analysis of solar photovoltaic power generation efficiency[J].technological innovation Herald, 2013,27: 64.

[18] JIANG Guodong. The discussion and analysis of world PV subsidy policy[J]. Telecom Power Technology, 2013, 30(5):47-50. 